\title{
PENGARUH PELAYANAN TERHADAP KEPUASAN PELANGGAN PADA BENGKEL GM AUDIO PEMATANGSIANTAR
}

\author{
Oleh: \\ Yohana Tania P.S \\ S1 Manajemen \\ Darwin Lie, Marisi Butarbutar, Efendi
}

\begin{abstract}
Abstraksi
Adapun tujuan penelitian ini untuk mengetahui gambaran dan pengaruh pelayanan terhadap kepuasan pelanggan pada Bengkel GM Audio Pematangsiantar. Dalam menganalisa permasalahan, penulis melakukan penelitian kepustakaan dan penelitian lapangan. Untuk menganalisis data digunakan teknik analisa deskriptif kualitatif dan teknik analisa deskriptif kuantitatif. Hipotesis penelitian adalah pelayanan yang diberikan berpengaruh positif terhadap kepuasan pelanggan pada Bengkel GM Audio Pematangsiantar.

Hasil analisa menunjukkan $\hat{Y}=0,842+0,58 \mathrm{X}$ bertanda positip. Kekuatan hubungan kedua variabel ad alah sangat kuat yaitu sebesar 0,89. Dari perhitungan koefisien determinasi, diperoleh $79,21 \%$ tinggi rendahnya kepuasan pelanggan dapat dijelaskan oleh pelayanan, sisanya sebesar 20,79\% dapat dijelaskan oleh faktor lain seperti produk, harga, dan lainnya dalam penelitian ini. Pengujian hipotesis melalui uji $t$, dimana hasil uji $t_{\text {hit }}>$ $\mathrm{t}_{\text {tab. }}$. Untuk itu dalam meningkatkan kepuasan pelanggan, Bengkel GM Audio Pematangsiantar harus terus meningkatkan kualitas kerja karyawan, melengkapi peralatan-peralatan yang diperlukan, meningkatkan kecepatan dalam pelayanan serta mencoba dan mempertimbangkan biaya yang diberikan kepada pelanggan Bengkel GM Audio Pematangsiantar.
\end{abstract}

Kata Kunci: Pelayanan dan Kepuasan Pelanggan

\section{Abstraction}

As for this research target to know the picture and service influence to satisfaction of customer at Workshop of GM Audio Pematangsiantar. In analysis problems, writer conduct the research of bibliography and field research. To analyze the data used by a descriptive analysis technique qualitative and quantitative descriptive analysis technique. Research hypothesis is service given have an effect on positive to satisfaction of customer at Workshop of GM of Audio Pematangsiantar

Result of analysis show $?=0,842+0,58 \mathrm{X}$ of have sign to positive. Second relation strength of variable is very strong that is equal to 0,89. From calculation of coefficient determination, obtained by 79,21\% lower the explainable customer satisfaction by service, the rest of equal to 20,79\% by other factor like product, price, and other in this research. Hypothesis examination of through test $t$, where result test the $t_{\text {hit }}>t_{\text {tab. }}$. For that in improving customer satisfaction, Workshop of GM Audio Pematangsiantar have to be non-stop to improve the quality work the employees, needed equipments, improving speed in service and also try and consider the expense which is passed to customer of Workshop of GM Audio Pematangsiantar

Keyword: Service And Customer Satisfaction

\section{A. PENDAHULUAN}

\section{Latar Belakang Masalah}

Kepuasan pelanggan adalah hasil yang dirasakan oleh pembeli yang mengalami kinerja sebuah perusahaan yang sesuai dengan harapannya. Seperti halnya Bengkel GM Audio Pematangsiantar yang selama ini selalu berupaya untuk memberikan kepuasan kepada pelanggannya. Dalam memberikan kepuasan kepada pelanggan, Bengkel GM Audio Pematangsiantar mengharapkan pelanggan akan datang kembali untuk memanfaatkan jasa yang ditawarkan oleh Bengkel GM Audio Pematangsiantar. Bengkel GM Audio Pematangsiantar selalu menjual produk atau jasa dengan kualitas yang baik dengan harga terjangkau. Selain itu, Bengkel GM Audio Pematangsiantar selalu berusaha memberikan kenyamanan dalam pelayanan kepada pelanggan. Kesemua itu digunakan untuk memuaskan pelanggan. Pelanggan yang puas yang berkisar sebanyak $50 \%$, dapat dilihat dari pelanggan yang datang berulang-ulang. Sedangkan pelanggan yang tidak atau kurang puas yang berkisar $20 \%$, dapat dilihat dari keluhan tentang kekurang puas atau berhenti untuk datang kembali. Sisanya adalah pelanggan yang datang hanya sekali sebanyak $30 \%$.

Oleh karena itu, Pelayanan yang diberikan Bengkel GM Audio Pematangsiantar dalam hal ini diukur dengan kualitas pelayanan sebagai berikut: reliabilitas misalnya, mengatasi masalah dengan cepat dan selesai sesuai dengan waktu yang dijanjikan, daya tanggap misalnya, mudah diakses, tidak lama menunggu dan responsif terhadap permintaan, jaminan misalnya mekanik yang berpengaruh luas, empati misalnya mengenal nama pelanggan, mengingat masalah dan preferensi 
pelanggan sebelumnya, dan bukti fisik misalnya, fasilitas reparasi, ruang tunggu, seragam dan peralatan. Untuk dapat mempertahankan dan meningkatkan pelanggan aktual, maka Bengkel GM Audio Pematangsiantar perlu senantiasa mengukur bagaimana pelayanan yang baik untuk menciptakan tingkat kepuasan pelanggan terhadap unsur-unsur usaha baik dari manajemen usaha bahkan sampai dengan pelayanan usaha.

\section{Rumusan Masalah}

a. Bagaimana gambaran pelayanan dan kepuasan pelanggan pada Bengkel GM Audio Pematangsiantar?

b. Seberapa besar pengaruh pelayanan terhadap kepuasan pelanggan pada Bengkel GM Audio Pematangsiantar?

\section{Tujuan Penelitian}

a. Untuk mengetahui gambaran pelayanan dan kepuasan pelanggan pada Bengkel GM Audio Pematangsiantar.

b. Untuk mengetahui besarnya pengaruh pelayanan terhadap kepuasan pelanggan pada Bengkel GM Audio Pematangsiantar.

\section{Metode Penelitian}

Desain penelitian merupakan suatu cara yang sistematis dan objektif dengan maksud untuk memperoleh data atau mengumpulkan keterangan untuk diteliti. Adapun Desain penelitian yang digunakan adalah Penelitian Kepustakaan (Library Research) dan Penelitian Lapangan (Field Research).

Teknik pengumpulan data yang dilakukan penulis dalam penelitian ini adalah berupa Kuesioner, Wawancara dan Dokumentasi. Tehnik analisa data yang digunakan dalam penelitian ini antara lain Tehnik Analisa Deskriptif Kualitatif dan Tehnik Analisa Deskriptif Kuantitatif.

\section{B. LANDASAN TEORI}

\section{Pelayanan}

Secara sederhana, istilah service mungkin bisa diartikan sebagai "melakukan sesuatu bagi orang lain". Menurut Stanton dalam Alma (2007:204), jasa adalah suatu yang dapat diidentifikasikan secara terpisah, tidak berwujud, ditawarkan untuk memenuhi kebutuhan jasa, dapat dihasilkan menggunakan benda-benda berwujud atau tidak. Selanjutnya menurut Zeithaml dan Bitner dalam Alma (2007:204), jasa (Service) adalah suatu kegiatan ekonomi yang hasilnya bukan produk, dikonsumsi bersamaan waktu produksi dan memberikan nilai tambah (seperti kenikmatan, liburan, santai, sehat (bersifat tidak berwujud). Menurut Tjiptono (2008:15) ada empat karakteristik jasa atau layanan, yaitu: tidak berwujud, bervariasi, tidak dapat dipisahkan, tidak tahan lama.

Menurut Nasution (2004:47), kualitas pelayanan adalah tingkat keunggulan yang diharapkan dan pengendalian atas tingkat keunggulan tersebut untuk memenuhi keinginan pelanggan. Menurut Garvin dalam Tjiptono (2008:93), terdapat 8 dimensi kualitas pelayanan, yaitu: Kinerja (performance), Fitur (features), Reliabilitas (reliability), Kesesuaian dengan spesifikasi (conformance to specifications), Daya tahan (durability), Serviceability, Estetika, Persepsi kualitas (perceived quality). menurut Tjiptono (2008:94) dapat disimpulkan menjadi 5 dimensi utama yang disusun sesuai urutan tingkat kepentingan relatifnya, yaitu:

a) Reliabilitas (reliability), berkaitan dengan kemampuan perusahaan untuk menyampaikan layanan yang dijanjikan secara akurat sejak pertama kali. Contohnya masalah diatasi dengan cepat dan selesai pada waktu yang dijanjikan.

b) Daya tanggap (responsiveness), berkenaan dengan kesediaan dan kemampuan penyedia layanan untuk membantu para pelanggan dan merespon permintaan mereka dengan segera. Contonya mudah diakses, tidak lama menunggu dan responsif terhadap permintaan.

c) Jaminan (assurance), berkenaan dengan pengetahuan dan kesopanan karyawan serta kemampuan mereka dalam menumbuhkan rasa percaya dan keyakinan pelanggan. Contohnya mekanik yang berpengetahuan luas.

d) Empati (emphaty), berarti bahwa perusahaan memahami masalah para pelanggan dan bertindak demi kepentingan pelanggan, serta memberikan perhatian personal kepada para pelanggan dan memiliki jam operasi yang nyaman. Contohnya mengenal nama pelanggan, mengingat masalah dan preferensi pelanggan sebelumnya.

e) Bukti fisik (tangibles), berkenaan dengan penampilan fisik fasilitas layanan, peralatan, perlengkapan, sumber daya manusia, dan materi komunikasi perusahaan. Contohnya fasilitas reparasi, ruang tunggu, seragam dan peralatan.

\section{Kepuasan Pelanggan}

Kepuasan pelanggan adalah hasil yang dirasakan oleh pembeli yang mengalami kinerja sebuah perusahaan yang sesuai dengan harapannya. Day dalam Nasution (2004:104), menyatakan bahwa Kepuasan Pelanggan adalah respons pelanggan terhadap evaluasi ketidaksesuaian yang dirasakan antara harapan sebelumnya dan kinerja aktual produk yang dirasakan setelah pemakaiannya. Engel dalam Nasution (2004:104), mengungkapkan bahwa kepuasan pelanggan merupakan evaluasi pembeli, dimana alternatif yang dipilih sekurang-kurangnya memberikan hasil sama atau melampaui harapan pelanggan, sedangkan ketidakpuasan timbul apabila hasil yang diperoleh tidak memenuhi harapan pelanggan. Drucker dalam Nasution (2004:104) mengatakan bahwa bagi pelanggan, apa yang dihasilkan suatu perusahaan adalah tidak begitu penting. Pelanggan memikirkan apa yang akan dibelinya untuk memuaskan kebutuhannya atas dasar pertimbangan nilai yang diterimanya. Ini berarti kita harus memberikan apa yang sebenarnya 
mereka inginkan, kapan, dan cara mereka memperolehnya.

Menurut Lupiyoadi dan Hamdani (2006:192), ada empat faktor utama yang perlu diperhatikan dalam kaitannya dengan kepuasan pelanggan yaitu:

a) Kualitas Produk atau Jasa, pelanggan akan puas bila hasil evaluasi mereka menunjukkan bahwa produk atau jasa yang mereka gunakan berkualitas.

b) Struktur Harga, yang mempunyai kualitas yang sama tetapi menetapkan harga yang relatif murah akan memberikan nilai yang lebih tinggi kepada pelanggannya.

c) Kenyamanan Prosedur, yaitu pelanggan akan merasa semakin puas jika dalam mendapatkan prosedur pelayanan relatif mudah, nyaman, dan efisien.

d) Dukungan Konsumen, pelanggan akan merasa bangga dan mendapatkan keyakinan bahwa orang lain akan kagum bila seseorang menggunakan produk maupun jasa yang cenderung mempunyai kepuasan yang lebih tinggi. Kepuasan yang diperoleh bukan karena kualitas dari produk atau jasa, tetapi nilai sosial yang membuat pelanggan menjadi puas dengan merek ataupun pelayanan tertentu.

Untuk menghindari ketidakpuasan pelanggan, Kotler dalam Tjiptono dan Gregorius (2011:314) mengemukakan beberapa metode untuk mengukur kepuasan pelanggan, yakni: Sistem Keluhan dan Saran, Survei Kepuasan Pelanggan, Direct Reported Satisfaction, Derived Dissatisfaction, Analisa Masalah, Importence-performance Analysis, Ghost Shopping, Lost Customer Analysis. Menurut Lovelock dan Wright (2005:105), kepuasan yang tinggi merupakan polis asuransi terhadap sesuatu yang salah, yang tidak akan terhindarkan karena adanya keragaman yang terkait dengan produksi jasa.

\section{PEMBAHASAN}

\section{Analisa}

\section{a. Analisa Deskriptif Kualitatif}

Analisa deskriptif dimaksudkan untuk mendapatkan gambaran atau deskriptif mengenai tanggapan dari konsumen mengenai pengaruh pelayanan terhadap kepuasan pelanggan pada Bengkel GM Audio Pematangsiantar. sesudah pengujian data, maka langkah selanjutnya peneliti melakukn pengkajian analisis kualitatif sebagai gambaran fenomenal dari variabel penelitian pada saat sekarang ini.

\section{1) Gambaran Pelayanan}

Pelayanan pelanggan adalah salah satu faktor utama yang dilakukan oleh bengkel GM Audio. Bengkel GM Audio adalah bengkel yang bergerak dalam bidang jasa dengan prinsip mementingkan kualitas dari pada kuantitas dengan kegiatan utamanya antara lain adalah service dan reparasi Air Conditioner (AC) mobil, ganti oli mesin mobil, serta pispot. Dari lima dimensi pelayanan, dapat disimpulkan bahwa pelayanan yang diberikan oleh Bengkel GM Audio Pematangsiantar sudah baik berada pada nilai rata-rata 3,84. Hal tersebut dikarenakan Bengkel GM Audio Pematangsiantar selalu berusaha untuk menjaga pelanggan agar tidak pindah ke bengkel lain serta berusaha menarik pelanggan potensial. Oleh karena itu, Bengkel GM Audio Pematangsiantar selalu berusaha untuk terus memperbaiki pelayanan yang akan diberikan kepada pelanggan.

\section{2) Gambaran Kepuasan Pelanggan}

Faktor terpenting yang mempengaruhi kepuasan pelanggan pada Bengkel GM Audio Pematangsiantar adalah berdasarkan pelayanan yang diberikan kepada pelanggan. Bengkel GM Audio Pematangsiantar adalah bengkel yang bergerak dalam bidang penjualan barang dan jasa dengan kegiatan utama adalah service dan reparasi air conditioner (AC) mobil. Dalam menjalankan kegiatan usahanya, Bengkel GM Audio Pematangsiantar melakukan pelayanan kepada konsumen untuk menciptakan kepuasan pelanggan.

Bengkel GM Audio Pematangsiantar memakai empat faktor yang mempengaruhi kepuasan pelanggan. Faktor tersebut diantaranya adalah kualitas produk atau jasa yaitu dengan menjual beberapa produk yang berkualitas, struktur harga yaitu dengan penetapan harga yang terjangkau dengan produk yang ditawarkan berkualitas, kenyamanan prosedur yaitu dengan memberi kemudahan dan efisiensi saat melakukan service, dan dukungan konsumen yaitu meyakinkan pelanggan bahwa pelayanan yang diterima akan maksimal dan memuaskan.

Dari empat dimensi kepuasan pelanggan, dapat dinyatakan bahwa pelanggan Bengkel GM Audio Pematangsiantar dengan keseluruhan termasuk dalam kategori puas pada nilai rata-rata 3,85. Kepuasan tersebut didapat dari kualitas produk atau jasa, harga yang diberikan, kemudahan dalam prosedur pelayanan, serta dukungan dari konsumen. Kepuasan yang terus diupayakan untuk pelanggan memiliki manfaat untuk mengisolasi pelanggan dari persaingan, menciptakan keunggulan yang berkelanjutan, mengurangi biaya kegagalan, mendorong loyalitas, mempromosikan dari mulut ke mulut, serta menurunkan biaya promosi untuk mendapatkan pelanggan baru.

\section{b. Analisa Deskriptif Kuantitatif}

\section{Regresi Linier Sederhana}

Analisis regresi sederhana digunakan untuk mengetahui pengaruh variabel bebas (X) dan variabel terikat (Y), dimana $\mathrm{X}$ adalah Pelayanan, dan $\mathrm{Y}$ adalah Kepuasan Pelanggan. Analisis dilakukan dengan melakukan tabulasi jawaban responden pada kuesioner yang telah dijalankan. Untuk melihat pengaruh variabel dengan persamaan regresi tersebut, maka dilakukan perhitungan secara manual untuk memperoleh nilai a dan $b$, dengan notasi sebagai berikut: $\hat{Y}=a+b X$. 
Berdasarkan hasil pengolahan data didapat persamaan regresi linear sederhana yaitu $\hat{Y}=$ $0,842+0,58 \mathrm{X}$ bertanda positip, yaitu terdapat pengaruh yang positip antara variabel $\mathrm{X}$ (Pelayanan) terhadap variabel $\mathrm{Y}$ (Kepuasan Pelanggan) pada Bengkel GM Audio Pematangsiantar, dimana semakin baik pelayanan yang diberikan maka semakin tinggi pula kepuasan yang diperoleh pelanggan.

\section{Korelasi dan Koefisien Determinasi}

Selanjutnya dilakukan perhitungan korelasi berupa derajat atau kedalaman hubungan fungsional yang menjelaskan hubungan antar perubah, dinyatakan dengan yang dinamakan koefisien korelasi yang sering disimbolkan dengan $r$. Nilai $r$ dapat dihitung sebagai berikut:

$$
\mathrm{r}=\frac{n \sum X Y-\sum X \sum Y}{\sqrt{n \sum X^{2}-\left(\sum X\right)^{2}} \sqrt{n \sum Y^{2}-\left(\sum Y\right)^{2}}}
$$

$r=0,89$

Dari hasil perhitungan diatas, diperoleh nilai $r=0,89$, artinya terdapat hubungan yang sangat kuat antara variabel $\mathrm{X}$ yaitu pelayanan terhadap variabel Y yaitu kepuasan pelanggan. Kemudian untuk mengukur seberapa besar kontribusi variabel bebas menjelaskan variabel terikat maka digunakan koefisien determinasi (R). Nilai R dapat diperoleh dari::

$$
\begin{aligned}
& \mathrm{KD}=\mathrm{r}^{2} \times 100 \% \\
& \mathrm{KD}=79,21 \%
\end{aligned}
$$

Hasil KD ditas menunjukkan tinggi rendahnya atau naik turunnya kepuasan pelanggan sebesar $79,21 \%$ dapat dijelaskan oleh pelayanan, sisanya sebesar $20,79 \%$ dapat dijelaskan oleh faktor lain seperti produk, harga dan lainnya dalam penelitian ini.

\section{Uji Hipotesis (uji t)}

Untuk menguji hasil perhitungan regresi dapat dilakukan pembuktian hipotesa untuk mengetahui apakah variabel bebas mempunyai pengaruh atau tidak terhadap variabel terikat secara parsial. Dengan kriteria pengujian yaitu:

a. Jika , maka Ho ditolak dan Ha diterima, artinya pelayanan berpengaruh positif terhadap kepuasan pelanggan,

b. Jika , maka Ho diterima dan Ha ditolak, artinya pelayanan tidak berpengaruh positif terhadap kepuasan pelanggan.

Dengan kriteria pengujian yaitu: jika $\mathrm{t}_{\text {hit }}<\mathrm{t}_{\text {tab }}$ atau probabilitas signifikansi $<\alpha(5 \%)$, maka Ho diterima dan Ha ditolak. Jika $t_{\text {hit }}>t_{\text {tab }}$ atau probabilitas signifikansi $>\alpha(5 \%)$, maka Ho ditolak dan Ha diterima. Dengan $\alpha=0,05$ di mana $n=30$, maka nilai t hitung dapat dicari sebagai berikut:

$$
\mathrm{t}=\frac{\mathrm{r} \sqrt{\mathrm{n}-2}}{\sqrt{1-\mathrm{r}^{2}}}
$$

Dari hasil pengujian sebesar 10,33 sedangkan pada tingkat signifikansi $\alpha=5 \%$ adalah sebesar 2,048. Oleh karena , berarti variabel pelayanan berpengaruh terhadap kepuasan pelanggan, sehingga Ho ditolak dan Ha diterima, artinya pelayanan berpengaruh positif terhadap kepuasan pelanggan Bengkel GM Audio Pematangsiantar.

\section{Evaluasi \\ a. Pelayanan \\ Masih terdapat indikator pelayanan yang} berada dibawah nilai-rata-rata. Seperti pada indikator bukti fisik berupa area servis yang masih memliki nilai yang paling rendah dibandingkan dengan pertanyaan lain yang diberikan kepada pelanggan. Selain itu peralatan yang dimiliki oleh Bengkel GM Audio Pematangsiantar juga dinilai masih rendah walaupun sudah tergolong dalam kriteria puas. Oleh karena itu penting bagi Bengkel GM Audio Pematangsiantar untuk berusaha melengkapi peralatan-peralatan yang masih kurang. Selain bukti fisik, indikator jaminan dan daya tanggap juga perlu diperhatikan. Bengkel GM Audio pematangsiantar diharapkan lebih memperhatikan karyawannya ketika bekerja, melihat kesesuaian pekerjaan yang dilakukan oleh karyawannya serta informasi yang diberikan harus lebih akurat sehingga pelanggan benar-benar merasakan kepuasan.

Bengkel GM Audio Pematangsiantar dalam indikator reabilitas dan empatinya, sudah memiliki kriteria penilaian yang sudah baik. Walaupun memiliki penilaian yang paling tinggi dibandingkan indikator lainnya, namun kedua indikator tersebut harus terus ditingkatkan. Bengkel GM Audio Pematangsiantar harus lebih teliti dalam melakukan pekerjaannya serta berusaha memberikan kenyamanan dengan cara memberikan potongan biaya kepada pelanggan.

\section{b. Kepuasan Pelanggan}

Dalam menciptakan kepuasan pelanggannya, Bengkel GM Audio Pematangsiantar tentu tidak luput dari kekurangan. Pada faktor dukungan konsumen, pelanggan menilai bahwa kecepatan dalam pelayanan yang diberikan serta biaya yang diberikan oleh Bengkel GM Audio Pematangsiantar serta sudah baik secara umum. Namun jika dibandingkan dengan faktor lainnya, maka hal tersebut masih merupakan nilai terendah. Oleh sebab itu, Bengkel GM Audio Pematangsiantar harus melakukan perbaikan dengan cara meningkatkan kecepatan dalam pelayanan serta mencoba dan mempertimbangkan biaya yang diberikan kepada pelanggan. Bengkel GM Audio Pematangsiantar harus dapat mengurangi biaya yang diberikan kepada pelanggan tanpa mengurangi kualitas yang telah baik.

Selain kekurangan tersebut, Bengkel GM Audio Pematangsiantar juga memiliki keunggulan. Keunggulan dalam bidang kualitas produk, dan keramahan dalam pelayanan harus dapat dipertahankan serta ditingkatkan. Keunggulan 
tersebut dikarenakan, Bengkel GM Audio Pematangsiantar dalam menjual produknya, merupakan produk yang berkualitas sehingga pelanggan merasa puas akan produk yang ditawarkan tersebut. Selain itu, karyawan Bengkel GM Audio Pematangsiantar selalu memberikan pelayanan dengan sopan santun tanpa mengurangi kualitas kinerja mereka.

\section{KESIMPULAN DAN SARAN}

\section{Kesimpulan}

a. Dari segi pelayanan keseluruhan responden sudah menyatakn baik dengan nilai rata-rata 3,84. Dari segi kepuasan pelanggan dengan nilai rata-rata jawaban keseluruhan responden 3,85 sudah termasuk kriteria puas.

b. Hasil regresi linear sederhana yaitu $\hat{Y}=$ $0,842+0,58 \mathrm{X}$ bertanda positip, yaitu terdapat pengaruh yang positip Pelayanan terhadap Kepuasan Pelanggan.

c. Perhitungan korelasi menunjukkan hubungan yang sangat kuat dan positi dengan nilai $r=0.89$ dan koefisien determinasi sebesar 79,21\% tinggi rendahnya kepuasan pelanggan dapat dijelaskan kontribusi pelayanan.

d. Pengujian hhipotesis dengan uji $\mathrm{t}$ diperoleh $t_{\text {hit }} 10,33>t_{\text {tab }} 2,048$. Berarti pelayanan berpengaruh positip terhadap kepuasan pelanggan pada bengkel GM Adio Pematangsiantar, sehingga Ho ditolak.

\section{Saran}

a. Dalam hal pelayanan, Bengkel GM Audio Pematangsiantar diharapkan dapat meningkatkan pelayanan kepada konsumen seperti melengkapi peralatan-peralatan yang diperlukan untuk melakukan perbaikan, meningkatkan kualitas kerja karyawan sehingga konsumen akan merasa puas akan pelayanan yang diberikan.

b. Dalam hal kepuasan pelanggan, Bengkel GM Audio Pematangsiantar juga perlu melakukan perbaikan pada faktor kepuasan pelanggan seperti meningkatkan kecepatan dalam pelayanan serta mencoba dan mempertimbangkan biaya yang diberikan kepada pelanggan. Bengkel GM Audio Pematangsiantar harus dapat mengurangi biaya yang diberikan kepada pelanggan tanpa mengurangi kualitas yang telah baik. Selain itu, keunggulan dalam bidang kualitas produk dan keramahan dalam pelayanan harus dapat dipertahankan serta ditingkatkan untuk menghasilkan kepuasan yang lebih optimal.

\section{E. DAFTAR PUSTAKA}

Alma, Buchari. Manajemen Dan Pemasaran Jasa. Bandung : Alfabeta, 2007

Boyd, et. al, Manajemen Pemasaran : Suatu Pendekatan Strategis Dengan Orientasi Global. Erlangga: Jakarta, 2000.
Kotler, Philip. Manajemen Pemasaran, Edisi 13. Jilid 1-2. Erlangga: Jakarta, 2009

Lovelock, Christopher. H \& Wright, S. Laurence. Manajemen Pemasaran Jasa. Indeks: Jakarta, 2005.

Lupiyoadi, Rambat \& Hamdani, A. Manajemen Pemasaran Jasa, Edisi 2. Salemba Empat: Jakarta, 2006

Nasution, Drs. M. N., M.Sc.,A.P.U. Manajemen Jasa Terpadu. Ghalia Indonesia: Bogor, 2004. Manajemen Mutu Terpadu. Ghalia Indonesia: Bogor, 2004.

Nazir, Moh. Metode Penelitian. Ghalia Indonesia: Bogor, 2003.

Sari

Ratna.

2010. http://tesisdisertasi.blogspot.com/2010/07/k arakteristik-pelayanan.html. 2012

Simbolon, Hotman. Statistika. Graha Ilmu: Yogyakarta, 2009.

Sugiono. Metode Penelitian Kuantitatif Kualitatif Dan R\&D. CV. Alfabeta: Bandung, 2010

Statistika Untuk Penelitian. CV. Alfabeta: Bandung, 2010

Tjiptono, Fandy. Manajemen Pemasaran Jasa. Andi: Yogyakarta, 2000 Service Management: Mewujudkan Layanan Prima. Andi: Yogyakarta, 2008

Tjiptono, Ph.d, Fandy \& Gregorius Chandra, Service, Quality \& Satisfaction, Edisi ketiga. Andi: Yogyakarta, 2011.

Umar, Husein. Metode Riset Perilaku Konsumen Jasa. Ghalia Indonesia: Bogor, 2004. 